TITLE:

\title{
Thermodynamic Properties of Solid Solutions between Di-calcium Silicate and Tri-calcium Phosphate
}

\author{
AUTHOR(S): \\ Hasegawa, M.; Kashiwaya, Y.; Iwase, M.
}

\section{CITATION:}

Hasegawa, M....[et al]. Thermodynamic Properties of Solid Solutions between Di-calcium Silicate and Tri-calcium Phosphate. High Temperature Materials and Processes 2012, 31(4-5): 421-430

ISSUE DATE:

2012-01-30

URL:

http://hdl.handle.net/2433/182959

RIGHT:

(C) 2012 by Walter de Gruyter 
M. Hasegawa*, Y. Kashiwaya and M. Iwase

\section{Thermodynamic Properties of Solid Solutions between Di-calcium Silicate and Tri-calcium Phosphate}

\begin{abstract}
For a better understanding of phosphorus removal from hot metal, the Gibbs free energies of solid solutions between di-calcium silicate and tri-calcium phosphate were derived through applications of solutions models. The regular solution model with the parameters determined in this study gave the activities of the components thermodynamically consistent with the literature data and the phase diagrams.
\end{abstract}

Keywords: di-calcium silicate, tri-calcium phosphate, solid solution, dephosphorization

PACS $^{\circledR}$ (2010). 82.60.-S

* Corresponding author: M. Hasegawa: Department of Energy Science and Technology, Kyoto University, Kyoto 606-8501, Japan E-mail: hasegawa@energy.kyoto-u.ac.jp

Y. Kashiwaya: Department of Energy Science and Technology, Kyoto University, Kyoto 606-8501, Japan

M. Iwase: Department of Energy Science and Technology, Kyoto University, Kyoto 606-8501, Japan

\section{Introduction}

The ternary system, calcium oxide-silicon oxidephosphorus oxide, constitutes one of the most fundamental steelmaking slags. Figure 1(a) gives the iso-thermal section of the ternary system $\mathrm{CaO}-\mathrm{SiO}_{2}-\mathrm{P}_{2} \mathrm{O}_{5}$ near the $\mathrm{CaO}$ apex at $1573 \mathrm{~K}$, determined by the present authors $/ 1 /$. As can be seen in Figure 1(a), this system has the following double oxides;

$$
\begin{array}{ll}
\text { di-calcium silicate } & \mathrm{Ca}_{2} \mathrm{SiO}_{4}=2 \mathrm{CaO} \cdot \mathrm{SiO}_{2}=C_{2} \mathrm{~S} \\
\text { tri-calcium silicate } & \mathrm{Ca}_{3} \mathrm{SiO}_{5}=3 \mathrm{CaO} \cdot \mathrm{SiO}_{2}=C_{3} \mathrm{~S} \\
\text { tri-calcium phosphate } & \mathrm{Ca}_{3} \mathrm{P}_{2} \mathrm{O}_{8}=3 \mathrm{CaO} \cdot \mathrm{P}_{2} \mathrm{O}_{5}=C_{3} P \\
\text { tetra-calcium phosphate } \mathrm{Ca}_{4} \mathrm{P}_{2} \mathrm{O}_{9}=4 \mathrm{CaO} \cdot \mathrm{P}_{2} \mathrm{O}_{5}=C_{4} P
\end{array}
$$

It has been known that solid solutions form between di-calcium silicate, $\mathrm{Ca}_{2} \mathrm{SiO}_{4}$, and tri-calcium phosphate,

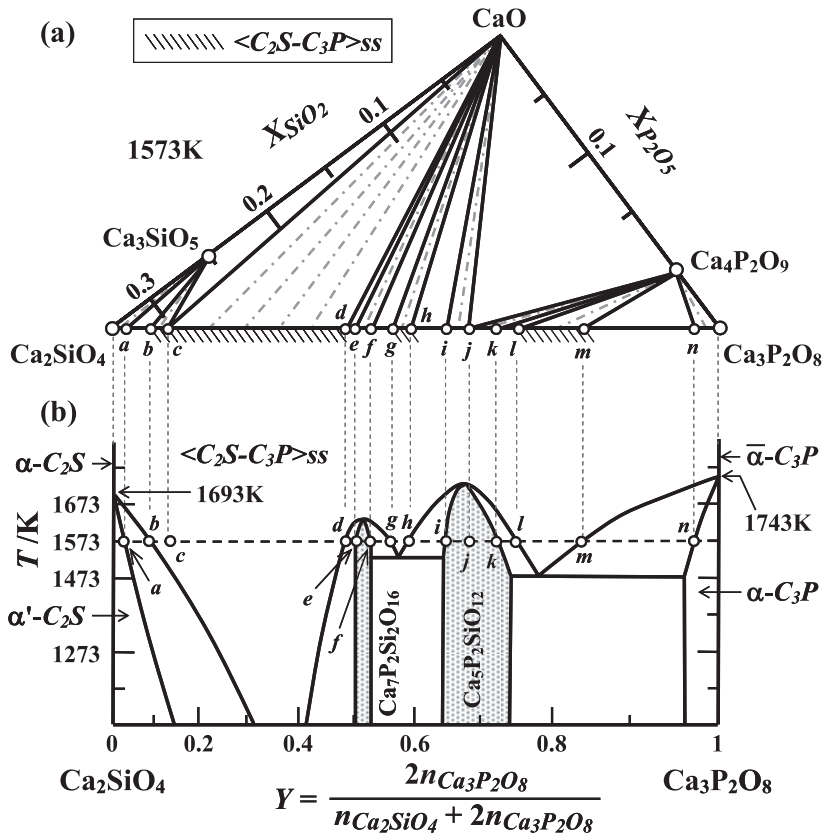

Fig. 1: (a) Iso-thermal section of the ternary system $\mathrm{CaO}-\mathrm{SiO}_{2}-\mathrm{P}_{2} \mathrm{O}_{5}$ near the $\mathrm{CaO}$ apex at $1573 \mathrm{~K}$. (b) Phase diagram of the pseudobinary system $\mathrm{Ca}_{2} \mathrm{SiO}_{4}-\mathrm{Ca}_{3} \mathrm{P}_{2} \mathrm{O}_{8}$.

$\mathrm{Ca}_{3} \mathrm{P}_{2} \mathrm{O}_{8}$. Figure $1(\mathrm{~b})$ shows the pseudo-binary phase diagram of $\mathrm{Ca}_{2} \mathrm{SiO}_{4}-\mathrm{Ca}_{3} \mathrm{P}_{2} \mathrm{O}_{8}$ based upon the work of Fix et al. /2/ and includes the following triple oxides;

$$
\begin{aligned}
& \mathrm{Ca}_{7} \mathrm{P}_{2} \mathrm{Si}_{2} \mathrm{O}_{16}=7 \mathrm{CaO} \cdot \mathrm{P}_{2} \mathrm{O}_{5} \cdot 2 \mathrm{SiO}_{2}=C_{7} P S_{2} \\
& \mathrm{Ca}_{5} \mathrm{P}_{2} \mathrm{SiO}_{12}=5 \mathrm{CaO} \cdot \mathrm{P}_{2} \mathrm{O}_{5} \cdot \mathrm{SiO}_{2}=C_{5} P S
\end{aligned}
$$

Figure 1(b) illustrates that the temperatures of the phase transformations from $\alpha^{\prime}-C_{2} S$ to $\alpha-C_{2} S$ and from $\alpha-C_{3} P$ to $\bar{\alpha}-C_{3} P$ are $1693 \mathrm{~K}$ and $1743 \mathrm{~K}$, respectively, and solid solutions $\left\langle C_{2} S-C_{3} P\right\rangle$ ss form between $\alpha-C_{2} S$ and $\bar{\alpha}-C_{3} P$. As seen in Figure 1(a), $\left\langle C_{2} S-C_{3} P\right\rangle$ SS can coexist with solid $\mathrm{CaO}$ at $1573 \mathrm{~K}$ although the stoichiometric compounds of $C_{2} S$ and $C_{3} P$ can not. This is consistent with the observation that, during phosphorus removal from hot metal, phosphorus would often be present in $\left\langle C_{2} S-C_{3} P\right\rangle$ sS coexisting with 
solid $\mathrm{CaO} / 3 /$. A better understanding of dephosphorization process would rely on the knowledge of the thermodynamic properties of $\left\langle C_{2} S-C_{3} P\right\rangle s s$, whereas there has been a definite lack of such data. The present study is aimed at deriving the activities of the components at 1573 $\mathrm{K}$ by applying solution models to $\left\langle C_{2} S-C_{3} P\right\rangle$ Ss.

\section{Calculation}

\subsection{Solution models}

Figure 1(b) reported by Fix et al. /2/ shows that solid solutions $\left\langle C_{2} S-C_{3} P\right\rangle$ SS could form between higher-temperature forms of $\mathrm{Ca}_{2} \mathrm{SiO}_{4}$ and $\mathrm{Ca}_{3} \mathrm{P}_{2} \mathrm{O}_{8}$, represented by $\alpha-C_{2} S$ and $\bar{\alpha}-C_{3} P$, respectively. The lattice structures of these solid phases have not been clarified /2/. As illustrated schematically in Figure 2, however, it is not unacceptable that electrically neutral molecules of " $(1 / 2) \mathrm{Ca}_{3} \mathrm{P}_{2} \mathrm{O}_{8}$ ” would replace with those of " $\mathrm{Ca}_{2} \mathrm{SiO}_{4}$ ", depending on compositions of solid solutions. Such a simple assumption derives the definition of the substitution ratio $Y$, given as

$$
Y \equiv n_{(1 / 2) \mathrm{Ca}_{3} \mathrm{P}_{2} \mathrm{O}_{8}} /\left(n_{\mathrm{Ca}_{2} \mathrm{SiO}_{4}}+n_{(1 / 2) \mathrm{Ca}_{3} \mathrm{P}_{2} \mathrm{O}_{8}}\right)
$$

where $n_{i}$ denotes the number of moles of component $i$ in solid solutions. The consideration that the molecular mass of " $(1 / 2) \mathrm{Ca}_{3} \mathrm{P}_{2} \mathrm{O}_{8}$ " is half of that of $\mathrm{Ca}_{3} \mathrm{P}_{2} \mathrm{O}_{8}$ leads to equation (2).

$$
n_{(1 / 2) C a_{3} P_{2} O_{8}}=2 n_{C a_{3} P_{2} O_{8}}
$$

Inserting equation (2) into equation (1), we have

$$
Y=2 n_{\mathrm{Ca}_{3} \mathrm{P}_{2} \mathrm{O}_{8}} /\left(n_{\mathrm{Ca}_{2} \mathrm{SiO}_{4}}+2 n_{\mathrm{Ca}_{3} \mathrm{P}_{2} \mathrm{O}_{8}}\right)
$$

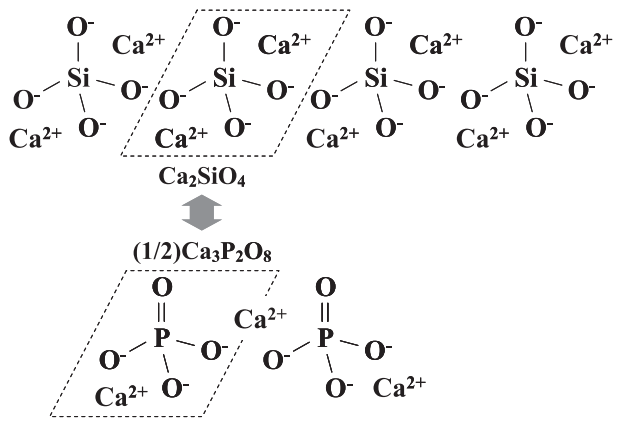

Fig. 2: Schematic illustration of solid solution between $\mathrm{Ca}_{2} \mathrm{SiO}_{4}$ and $\mathrm{Ca}_{3} \mathrm{P}_{2} \mathrm{O}_{8}$.
The present study is aimed at deriving the relative partial molar Gibbs free energies of $\mathrm{Ca}_{2} \mathrm{SiO}_{4}$ and $\mathrm{Ca}_{3} \mathrm{P}_{2} \mathrm{O}_{8}$ within $\left\langle C_{2} S-C_{3} P\right\rangle$ ss at $1573 \mathrm{~K}$. Towards this objective, the ideal solution model and the regular solution model were applied to solid solutions $\left\langle C_{2} S-C_{3} P\right\rangle$ ss between $\alpha-C_{2} S$ and $\bar{\alpha}-C_{3} P$. The activities of $\mathrm{Ca}_{2} \mathrm{SiO}_{4}$ and $\mathrm{Ca}_{3} \mathrm{P}_{2} \mathrm{O}_{8}$ referred to the most stable forms at $1573 \mathrm{~K}$ as standard states, i.e., $\alpha^{\prime}-C_{2} S$ and $\alpha-C_{3} P$, could be formulated as follows.

Ideal Solution Model

$$
\begin{aligned}
R T \ln a_{\mathrm{Ca}_{2} \mathrm{SiO}_{4}}= & \Delta G^{\circ}{ }_{t}\left(\mathrm{Ca}_{2} \mathrm{SiO}_{4}\right)+R T \ln (1-Y) \\
R T \ln a_{\mathrm{Ca}_{3} \mathrm{P}_{2} \mathrm{O}_{8}} & =2 R T \ln a_{(1 / 2) \mathrm{Ca}_{3} \mathrm{P}_{2} \mathrm{O}_{8}} \\
& =\Delta G^{\mathrm{o}}{ }_{t}\left(\mathrm{Ca}_{3} \mathrm{P}_{2} \mathrm{O}_{8}\right)+2 R T \ln Y
\end{aligned}
$$

Regular Solution Model

$$
\begin{aligned}
R T \ln a_{\mathrm{Ca}_{2} \mathrm{SiO}_{4}}=\Delta G^{\circ}{ }_{t}\left(\mathrm{Ca}_{2} \mathrm{SiO}_{4}\right)+R T \ln (1-Y)+\Omega Y^{2} \\
R T \ln a_{\mathrm{Ca}_{3} \mathrm{P}_{2} \mathrm{O}_{8}}=2 R T \ln a_{(1 / 2) \mathrm{Ca}_{3} \mathrm{P}_{2} \mathrm{O}_{8}} \\
=\Delta G^{\mathrm{o}}{ }_{t}\left(\mathrm{Ca}_{3} \mathrm{P}_{2} \mathrm{O}_{8}\right)+2 R T \ln Y+2 \Omega(1-Y)^{2}
\end{aligned}
$$

where $R$ is the gas constant, $\Delta G^{\circ}{ }_{t}\left(\mathrm{Ca}_{2} \mathrm{SiO}_{4}\right)$ and $\Delta G^{\circ}{ }_{t}\left(\mathrm{Ca}_{3} \mathrm{P}_{2} \mathrm{O}_{8}\right)$ represent the Gibbs free energy changes of the phase transformations of $\mathrm{Ca}_{2} \mathrm{SiO}_{4}$ and $\mathrm{Ca}_{3} \mathrm{P}_{2} \mathrm{O}_{8}$, respectively, and $\Omega$ is the interaction parameter independent of composition and temperature.

\subsection{Thermodynamic data used for calculations and necessary conditions}

Kubashewski, Alcock and Spencer listed the thermal data on $\mathrm{Ca}_{2} \mathrm{SiO}_{4}$, i.e., heat capacities of $\alpha^{\prime}-C_{2} S$ and $\alpha-C_{2} S$, and heat of the phase transformation /4/. By extrapolating the data for heat capacity of $\alpha-C_{2} S$ at temperature below $1693 \mathrm{~K}$, the value for $\Delta G^{\circ}{ }_{t}\left(\mathrm{Ca}_{2} \mathrm{SiO}_{4}\right)$ at $1573 \mathrm{~K}$ could be calculated as

$$
\begin{aligned}
\Delta G^{\mathrm{o}}{ }_{t}\left(\mathrm{Ca}_{2} \mathrm{SiO}_{4}\right) & \equiv G^{\mathrm{o}}\left(\alpha-C_{2} S\right)-G^{\circ}\left(\alpha^{\prime}-C_{2} S\right) \\
& =1,132 \mathrm{~J} \cdot \mathrm{mol}^{-1} \text { at } 1573 \mathrm{~K}
\end{aligned}
$$

where $G^{\circ}(i)$ is the standard Gibbs free energy of substance $i$. On the other hand, the literature data have been lacking for the calculation of $\Delta G^{\circ}{ }_{t}\left(\mathrm{Ca}_{3} \mathrm{P}_{2} \mathrm{O}_{8}\right)$. Therefore, the following formula was assumed in this study.

$$
\begin{aligned}
\Delta G^{\mathrm{o}}{ }_{t}\left(\mathrm{Ca}_{3} P_{2} \mathrm{O}_{8}\right) & \equiv G^{\mathrm{o}}\left(\bar{\alpha}-C_{3} P\right)-G^{\mathrm{o}}\left(\alpha-C_{3} P\right) \\
& =\Delta H^{\mathrm{o}}{ }_{t}\left(\mathrm{Ca}_{3} P_{2} O_{8}\right)(1-T / 1743)
\end{aligned}
$$

where $\Delta H^{\circ}{ }_{t}\left(\mathrm{Ca}_{3} \mathrm{P}_{2} \mathrm{O}_{8}\right)$ is the heat of the phase transportation from $\alpha-C_{3} P$ to $\bar{\alpha}-C_{3} P$ at the transition temperature of $1743 \mathrm{~K}$. 
The reactions of the formations of $\mathrm{Ca}_{2} \mathrm{SiO}_{4}$ and $\mathrm{Ca}_{3} \mathrm{SiO}_{5}$ from $\mathrm{CaO}$ and $\mathrm{SiO}_{2}$ are expressed as

$$
\begin{aligned}
& 2 \mathrm{CaO}+\mathrm{SiO}_{2}=\mathrm{Ca}_{2} \mathrm{SiO}_{4} \\
& 3 \mathrm{CaO}+\mathrm{SiO}_{2}=\mathrm{Ca}_{3} \mathrm{SiO}_{5}
\end{aligned}
$$

The present authors assessed the thermal data by Kubaschewski et al. /4/ to derive the equilibrium constants of reactions (10) and (11) thermodynamically consistent with phase diagrams; the results could be given as follows $/ 5 /$.

$$
\begin{aligned}
\log K(10) & =\log a_{\mathrm{Ca}_{2} \mathrm{SiO}_{4}}-2 \log a_{\mathrm{CaO}}-\log a_{\mathrm{SiO}_{2}} \\
& =4.78 \text { at } 1573 \mathrm{~K} \\
\log K(11) & =\log a_{\mathrm{Ca}_{3} \mathrm{SiO}_{5}}-3 \log a_{\mathrm{CaO}}-\log a_{\mathrm{SiO}_{2}} \\
& =4.80 \text { at } 1573 \mathrm{~K}
\end{aligned}
$$

where $a_{i}$ represents the activities of substance $i$ referred to pure $i$ of the most stable form at $1573 \mathrm{~K}$. For the standard Gibbs free energy changes of the formations of $\mathrm{Ca}_{3} \mathrm{P}_{2} \mathrm{O}_{8}$ and $\mathrm{Ca}_{4} \mathrm{P}_{2} \mathrm{O}_{9}$ from $\mathrm{CaO}$ and $\mathrm{P}_{2} \mathrm{O}_{5}$, the following literature data were accepted.

$$
3 \mathrm{CaO}+\mathrm{P}_{2} \mathrm{O}_{5}=\mathrm{Ca}_{3} \mathrm{P}_{2} \mathrm{O}_{8}
$$

$$
\begin{aligned}
& \begin{aligned}
& \Delta G(14)^{\circ}=-R T \ln K(14) \\
&=-776,300+18.6 \times(T / K)\left(\mathrm{J} \cdot \mathrm{mol}^{-1}\right) \quad / 6,7 / \\
& \log K(14)= \log a_{\mathrm{Ca}_{3} \mathrm{P}_{2} \mathrm{O}_{8}}-3 \log a_{\mathrm{CaO}}-\log a_{\mathrm{P}_{2} \mathrm{O}_{5}} \\
&= 24.80 \text { at } 1573 \mathrm{~K} \\
& 4 \mathrm{CaO}+\mathrm{P}_{2} \mathrm{O}_{5}=\mathrm{Ca}_{4} \mathrm{P}_{2} \mathrm{O}_{9}
\end{aligned}
\end{aligned}
$$

$$
\begin{aligned}
& \begin{aligned}
\Delta G(17)^{\circ}= & -R T \ln K(17) \\
= & -781,500+14.8 \times(T / \mathrm{K})\left(\mathrm{J} \cdot \mathrm{mol}^{-1}\right) \quad / 7 / \\
\log K(17) & =\log a_{{C a_{4} P_{2} O_{9}}-4 \log a_{C a O}-\log a_{P_{2} O_{5}}} \\
& =25.18 \text { at } 1573 \mathrm{~K}
\end{aligned}
\end{aligned}
$$

\begin{tabular}{|c|c|c|c|c|c|c|c|}
\hline Region & $Y$ in $\left\langle C_{2} S-C_{3} P\right\rangle s S$ & $a_{\mathrm{Ca}_{2} \mathrm{SiO}_{4}}$ & $a_{\mathrm{Ca}_{3} \mathrm{P}_{2} \mathrm{O}_{8}}$ & $\log a_{C a O}$ & $\log a_{\mathrm{SiO}_{2}}$ & $\log a_{P_{2} O_{5}}$ & Remark \\
\hline $\begin{array}{l}\left\langle C_{2} S-C_{3} P\right\rangle \text { SS }+\mathrm{Ca}_{2} \mathrm{SiO}_{4}+ \\
\mathrm{Ca}_{3} \mathrm{SiO}_{5} \\
\text { (triangle } b-a-\mathrm{Ca}_{3} \mathrm{SiO}_{5} \text { ) } \\
\end{array}$ & 0.088 & $0.995^{a)}$ & 0.016 & -0.02 & -4.75 & $-26.53^{a)}$ & $\begin{array}{l}\log a_{P_{2} \mathrm{O}_{5}}=-26.53 ; \\
\text { Eq. (28) } \\
a_{\mathrm{Ca}_{2} \mathrm{SiO}_{4}}<1 \text {; Eq. (20) }\end{array}$ \\
\hline $\begin{array}{l}\left\langle C_{2} S-C_{3} P\right\rangle \text { SS }+\mathrm{CaO}+ \\
\mathrm{Ca}_{5} \mathrm{P}_{2} \mathrm{SiO}_{12} \\
\text { (triangle } h-\mathrm{CaO}-i)\end{array}$ & 0.592 & 0.445 & $0.745^{b)}$ & 0.00 & -5.13 & -24.93 & $\begin{array}{l}a_{\mathrm{Ca}_{3} \mathrm{P}_{2} \mathrm{O}_{8}}<0.417 \\
\mathrm{Eq} .(25)\end{array}$ \\
\hline $\begin{array}{l}\left\langle\mathrm{C}_{2} \mathrm{~S}-\mathrm{C}_{3} \mathrm{P}\right\rangle \mathrm{SS}+\mathrm{Ca}_{4} \mathrm{P}_{2} \mathrm{O}_{9}+ \\
\mathrm{Ca}_{5} \mathrm{P}_{2} \mathrm{SiO}_{12} \\
\text { (triangle } l-\mathrm{Ca}_{4} \mathrm{P}_{2} \mathrm{O}_{9}-k \text { ) }\end{array}$ & 0.748 & 0.274 & $1.193^{b)}$ & -0.46 & -4.43 & -23.35 & $\begin{array}{l}0.417<a_{\mathrm{Ca}_{3} \mathrm{P}_{2} \mathrm{O}_{8}}<1 \text {; } \\
\text { Eq. (26) }\end{array}$ \\
\hline $\begin{array}{l}\left\langle C_{2} S-C_{3} P\right\rangle S S+\mathrm{Ca}_{4} \mathrm{P}_{2} \mathrm{O}_{9}+ \\
\mathrm{Ca}_{3} \mathrm{P}_{2} \mathrm{O}_{8} \\
\text { (triangle } m-\mathrm{Ca}_{4} \mathrm{P}_{2} \mathrm{O}_{9}-n \text { ) }\end{array}$ & 0.841 & 0.173 & $1.507^{b)}$ & -0.56 & -4.33 & -22.95 & $a_{\mathrm{Ca}_{3} \mathrm{P}_{2} \mathrm{O}_{8}}<1$; Eq. (21) \\
\hline
\end{tabular}

In this study, $a_{P_{2} \mathrm{O}_{5}}$ represents the activity of $\mathrm{P}_{2} \mathrm{O}_{5}$ referred to hypothetical pure liquid $\mathrm{P}_{2} \mathrm{O}_{5} / 8 /$.

As shown in Figure 1(a), the iso-thermal section of the $\mathrm{CaO}-\mathrm{SiO}_{2}-\mathrm{P}_{2} \mathrm{O}_{5}$ system near the $\mathrm{CaO}$ apex at $1573 \mathrm{~K}$ consists of the following three-phase assemblages.

$$
\begin{gathered}
\left\langle C_{2} S-C_{3} P\right\rangle s S+\mathrm{Ca}_{2} \mathrm{SiO}_{4}+\mathrm{Ca}_{3} \mathrm{SiO}_{5} \text {; triangle } b-a-\mathrm{Ca}_{3} \mathrm{SiO}_{5} \\
\left\langle C_{2} S-C_{3} P\right\rangle s S+\mathrm{CaO}+\mathrm{Ca}_{3} \mathrm{SiO}_{5} \text {; triangle } c \text {-CaO- } \mathrm{Ca}_{3} \mathrm{SiO}_{5} \\
\left\langle C_{2} S-C_{3} P\right\rangle s S+\mathrm{CaO}+\mathrm{Ca}_{7} \mathrm{P}_{2} \mathrm{Si}_{2} \mathrm{O}_{16} \text {; triangle } d \text {-CaO-e } \\
\left\langle C_{2} S-C_{3} P\right\rangle s S+\mathrm{CaO}+\mathrm{Ca}_{7} \mathrm{P}_{2} \mathrm{Si}_{2} \mathrm{O}_{16} \text {; triangle } g \text {-CaO-f } \\
\left\langle C_{2} S-C_{3} P\right\rangle s S+\mathrm{CaO}+\mathrm{Ca}_{5} \mathrm{P}_{2} \mathrm{SiO}_{12} \text {; triangle } h-\mathrm{CaO}-i \\
\mathrm{CaO}+\mathrm{Ca}_{4} \mathrm{P}_{2} \mathrm{O}_{9}+\mathrm{Ca}_{5} \mathrm{P}_{2} \mathrm{SiO}_{12} ; \text { triangle CaO- } \mathrm{Ca}_{4} \mathrm{P}_{2} \mathrm{O}_{9}-j \\
\left\langle C_{2} S-C_{3} P\right\rangle s S+\mathrm{Ca}_{4} \mathrm{P}_{2} \mathrm{O}_{9}+\mathrm{Ca}_{5} \mathrm{P}_{2} \mathrm{SiO}_{12} \text {; triangle } l-\mathrm{Ca}_{4} \mathrm{P}_{2} \mathrm{O}_{9}-k \\
\left\langle C_{2} S-C_{3} P\right\rangle s S+\mathrm{Ca}_{4} \mathrm{P}_{2} \mathrm{O}_{9}+\mathrm{Ca}_{3} \mathrm{P}_{2} \mathrm{O}_{8} \text {; triangle } m-\mathrm{Ca}_{4} \mathrm{P}_{2} \mathrm{O}_{9}-n
\end{gathered}
$$

It should be noticed here that the compounds of $\mathrm{Ca}_{2} \mathrm{SiO}_{4}$, $\mathrm{Ca}_{7} \mathrm{P}_{2} \mathrm{Si}_{2} \mathrm{O}_{16}, \mathrm{Ca}_{5} \mathrm{P}_{2} \mathrm{SiO}_{12}$ and $\mathrm{Ca}_{3} \mathrm{P}_{2} \mathrm{O}_{8}$ included in these threephase regions were non-stoichiometric. The compositions of points $a, b, d, e, f, g, h, i, k, l, m$ and $n$ could be read off by using the scales of the mole fractions of $\mathrm{SiO}_{2}$ and $\mathrm{P}_{2} \mathrm{O}_{5}$ in Figure 1(a), while those of points $c$ and $j$ have not been determined precisely $/ 1 /$. Table 1 summarizes the values for $Y$ in $\left\langle C_{2} S-C_{3} P\right\rangle$ ss at compositions $b, h, l$ and $m$. Based on

a) The values with superscript " $a$ " satisfied the necessary conditions.

b) The values with superscript "b" did not satisfy the necessary conditions.

Table 1: Calculation results of the ideal solution model with $\Delta H^{\circ}{ }_{t}\left(\mathrm{Ca}_{3} \mathrm{P}_{2} \mathrm{O}_{8}\right)=101 \mathrm{~kJ} \cdot \mathrm{mol}^{-1}$. 
the thermodynamic considerations of the phase relations, the conditions which the solution models should satisfy were mentioned below.

As seen in Figure 1(b), $\mathrm{Ca}_{3} \mathrm{P}_{2} \mathrm{O}_{8}$ is soluble in $\alpha^{\prime}-C_{2} S$; point $a$ represents the solubility limit at $1573 \mathrm{~K}$. Such a solubility requires that the $\mathrm{Ca}_{2} \mathrm{SiO}_{4}$ activity at point $a$ is to be less than unity. According to the Condenced Phase Rule, when three phases coexist in a three-component system, there is only one degree of freedom. This implies that for a particular temperature, there are zero degrees of freedom; the $\mathrm{Ca}_{2} \mathrm{SiO}_{4}$ activity is independent of the bulk composition in the three-phase region of $\left\langle C_{2} S-C_{3} P\right\rangle s S+\mathrm{Ca}_{2} \mathrm{SiO}_{4}+$ $\mathrm{Ca}_{3} \mathrm{SiO}_{5}$ (triangle $b-a-\mathrm{Ca}_{3} \mathrm{SiO}_{5}$ ). Namely, the $\mathrm{Ca}_{2} \mathrm{SiO}_{4}$ activity within $\left\langle C_{2} S-C_{3} P\right\rangle$ ss at point $b$ is equivalent to that at point $a$ and hence to be less than unity.

$$
\left.a_{\mathrm{Ca}_{2} \mathrm{SiO}_{4}}<1 \quad \text { (at point } b ; Y=0.088, T=1573 \mathrm{~K}\right)
$$

In analogy with this, for the three-phase region of $\left\langle C_{2} S-C_{3} P\right\rangle S S+\mathrm{Ca}_{4} \mathrm{P}_{2} \mathrm{O}_{9}+\mathrm{Ca}_{3} \mathrm{P}_{2} \mathrm{O}_{8}$ (triangle $m-\mathrm{Ca}_{4} \mathrm{P}_{2} \mathrm{O}_{9}-n$ ), the solubility of $\mathrm{Ca}_{2} \mathrm{SiO}_{4}$ in $\alpha-C_{3} P$ requires that the $\mathrm{Ca}_{3} \mathrm{P}_{2} \mathrm{O}_{8}$ activity within $\left\langle C_{2} S-C_{3} P\right\rangle s S$ at composition $m$ is less than unity.

$$
\left.a_{\mathrm{Ca}_{3} \mathrm{P}_{2} \mathrm{O}_{8}}<1 \quad \text { (at point } m ; Y=0.841, T=1573 \mathrm{~K}\right)
$$

The $\mathrm{P}_{2} \mathrm{O}_{5}$ activity within the three-phase assemblage of $\mathrm{CaO}+\mathrm{Ca}_{4} \mathrm{P}_{2} \mathrm{O}_{9}+\mathrm{Ca}_{5} \mathrm{P}_{2} \mathrm{SiO}_{12}$ (triangle $\mathrm{CaO}-\mathrm{Ca}_{4} \mathrm{P}_{2} \mathrm{O}_{9}-\mathrm{j}$ ) can be calculated from equation (19) with the unit activities of $\mathrm{CaO}$ and $\mathrm{Ca}_{4} \mathrm{P}_{2} \mathrm{O}_{9}$.

$$
\log a_{P_{2} O_{5}}=-\log K(17)=-25.18 \text { at } 1573 \mathrm{~K}
$$

Inserting equation (22) into equation (16), the activity of hypothetical solid $\mathrm{Ca}_{3} \mathrm{P}_{2} \mathrm{O}_{8}$ in the three-phase region of $\mathrm{CaO}+\mathrm{Ca}_{4} \mathrm{P}_{2} \mathrm{O}_{9}+\mathrm{Ca}_{5} \mathrm{P}_{2} \mathrm{SiO}_{12}$ can be evaluated as

$$
\begin{gathered}
\log a_{\mathrm{Ca}_{3} \mathrm{P}_{2} \mathrm{O}_{8}}=\log \mathrm{K}(14)-\log K(17)=-0.38 \text { at } 1573 \mathrm{~K} \\
a_{\mathrm{Ca}_{3} \mathrm{P}_{2} \mathrm{O}_{8}}=0.417 \text { at } 1573 \mathrm{~K}
\end{gathered}
$$

Along the $\mathrm{Ca}_{2} \mathrm{SiO}_{4}-\mathrm{Ca}_{3} \mathrm{P}_{2} \mathrm{O}_{8}$ edge in Figure $1(\mathrm{a})$, the $\mathrm{Ca}_{3} \mathrm{P}_{2} \mathrm{O}_{8}$ activity should increase with an increase in the $\mathrm{Ca}_{3} \mathrm{P}_{2} \mathrm{O}_{8}$ concentration. Therefore, the $\mathrm{Ca}_{3} \mathrm{P}_{2} \mathrm{O}_{8}$ activity in the threephase region of $\mathrm{CaO}+\mathrm{Ca}_{4} \mathrm{P}_{2} \mathrm{O}_{9}+\mathrm{Ca}_{5} \mathrm{P}_{2} \mathrm{SiO}_{12}$ is to be greater than that at point $h$ and is to be smaller than that at point $l$. Thus, we obtain the following inequalities.

$$
\begin{array}{rr}
a_{C a_{3} \mathrm{P}_{2} \mathrm{O}_{8}}<0.417 & \text { (at point } h ; Y=0.592, T=1573 \mathrm{~K}) \\
0.417<a_{\mathrm{Ca}_{3} \mathrm{P}_{2} \mathrm{O}_{8}}<1 & \text { (at point } l ; Y=0.748, T=1573 \mathrm{~K})
\end{array}
$$

The $\mathrm{P}_{2} \mathrm{O}_{5}$ activity in $\left\langle C_{2} S-C_{3} P\right\rangle$ ss at composition $b$ was determined by the present authors through a gas equilibrium method /9/. Molten copper containing phosphorus was brought to equilibrium with mixtures of $\left\langle C_{2} S-C_{3} P\right\rangle s S+$ $\mathrm{Ca}_{2} \mathrm{SiO}_{4}+\mathrm{Ca}_{3} \mathrm{SiO}_{5}$ in a stream of $\mathrm{Ar}+\mathrm{H}_{2}+\mathrm{H}_{2} \mathrm{O}$ gas mixtures. The results were expressed as

$$
\begin{gathered}
R T \ln a_{P_{2} O_{5}}=-1,106,000+194.7 \times(T / \mathrm{K}) \quad\left(\mathrm{J} \cdot \mathrm{mol}^{-1}\right) \\
\left.\log a_{P_{2} O_{5}}=-26.53 \quad \text { (at point } b, T=1573 \mathrm{~K}\right)
\end{gathered}
$$

On the other hand, by using equations (12), (13) and (16) with the unit activity of $\mathrm{Ca}_{3} \mathrm{SiO}_{5}, a_{P_{2} \mathrm{O}_{5}}$ in the three-phase region of $\left\langle C_{2} S-C_{3} P\right\rangle S S+\mathrm{Ca}_{2} \mathrm{SiO}_{4}+\mathrm{Ca}_{3} \mathrm{SiO}_{5}$ can be expressed as

$$
\begin{aligned}
\log a_{\mathrm{P}_{2} \mathrm{O}_{5}}= & 3 \log a_{\mathrm{Ca}_{2} \mathrm{SiO}_{4}}+\log a_{\mathrm{Ca}_{3} \mathrm{P}_{2} \mathrm{O}_{8}}-3 \log \mathrm{K}(10) \\
& +3 \log \mathrm{K}(11)-\log \mathrm{K}(14) \\
= & 3 \log a_{\mathrm{Ca}_{2} \mathrm{SiO}_{4}}+\log a_{\mathrm{Ca}_{3} \mathrm{P}_{2} \mathrm{O}_{8}} \\
& -24.74 \quad(\text { at } 1573 \mathrm{~K})
\end{aligned}
$$

Combining equations (28) and (29), we have

$$
\begin{gathered}
3 \log a_{C a_{2} \mathrm{SiO}_{4}}+\log a_{C a_{3} \mathrm{P}_{2} \mathrm{O}_{8}}=-1.79 \\
(\text { at point } b ; Y=0.088, T=1573 \mathrm{~K})
\end{gathered}
$$

Equation (30) should hold when the values for $a_{\mathrm{Ca}_{2} \mathrm{SiO}_{4}}$ and $a_{\mathrm{Ca}_{3} \mathrm{P}_{2} \mathrm{O}_{8}}$ at composition $b$ evaluated with the solution models are inserted.

\section{Calculation results}

When the ideal solution model was applied to solid solutions $\left\langle C_{2} S-C_{3} P\right\rangle s s$, combining equations (4), (5), (8) and (9) gave the following formulae for the activities of $\mathrm{Ca}_{2} \mathrm{SiO}_{4}$ and $\mathrm{Ca}_{3} \mathrm{P}_{2} \mathrm{O}_{8}$ at $1573 \mathrm{~K}$.

$$
\begin{aligned}
\log a_{\mathrm{Ca}_{2} \mathrm{SiO}_{4}}=3.76 \times 10^{-2}+\log (1-Y) \\
\log a_{\mathrm{Ca}_{3} \mathrm{P}_{2} \mathrm{O}_{8}}=2 \log a_{(1 / 2) \mathrm{Ca}_{3} \mathrm{P}_{2} \mathrm{O}_{8}} \\
=3.24 \times 10^{-6} \times \Delta H^{\circ}{ }_{t}\left(\mathrm{Ca}_{3} \mathrm{P}_{2} \mathrm{O}_{8}\right)+2 \log Y
\end{aligned}
$$

The ideal solution model used in this study had one undetermined parameter, viz., $\Delta H^{\circ}{ }_{t}\left(\mathrm{Ca}_{3} \mathrm{P}_{2} \mathrm{O}_{8}\right)$. Inserting equations (31) and (32) into equation (30), the value for $\Delta \mathrm{H}^{\circ}{ }_{t}\left(\mathrm{Ca}_{3} \mathrm{P}_{2} \mathrm{O}_{8}\right)$ could be determined as

$$
\Delta H^{\mathrm{o}}{ }_{t}\left(\mathrm{Ca}_{3} \mathrm{P}_{2} \mathrm{O}_{8}\right) / \mathrm{J} \cdot \mathrm{mol}^{-1}=1.01 \times 10^{5}
$$

Thus, the activities of $\mathrm{Ca}_{3} \mathrm{P}_{2} \mathrm{O}_{8}$ at $1573 \mathrm{~K}$ could be expressed as 
$\log a_{\mathrm{Ca}_{3} \mathrm{P}_{2} \mathrm{O}_{8}}=2 \log a_{(1 / 2) \mathrm{Ca}_{3} \mathrm{P}_{2} \mathrm{O}_{8}}=3.28 \times 10^{-1}+2 \log \mathrm{Y}$

Rewriting equations (31) and (34), we had

$$
\begin{gathered}
a_{\mathrm{Ca}_{2} \mathrm{SiO}_{4}}=1.09 \times(1-Y) \\
a_{(1 / 2) \mathrm{Ca}_{3} \mathrm{P}_{2} \mathrm{O}_{8}}=1.46 \times Y \\
a_{\mathrm{Ca}_{3} \mathrm{P}_{2} \mathrm{O}_{8}}=\left(a_{(1 / 2) \mathrm{Ca}_{3} \mathrm{P}_{2} \mathrm{O}_{8}}\right)^{2}=(1.46 \times Y)^{2}
\end{gathered}
$$

The numbers of 1.09 in equation (35) and 1.46 in equation (36), respectively, indicated the activities of $\alpha-\mathrm{Ca}_{2} \mathrm{SiO}_{4}$ with reference to $\alpha^{\prime}-\mathrm{Ca}_{2} \mathrm{SiO}_{4}$ as the standard state and that of $\bar{\alpha}$-“ $(1 / 2) \mathrm{Ca}_{3} \mathrm{P}_{2} \mathrm{O}_{8}$ ” with reference to $\alpha$-“ $(1 / 2) \mathrm{Ca}_{3} \mathrm{P}_{2} \mathrm{O}_{8}$ ” as the standard state at $1573 \mathrm{~K}$. Dotted lines in Figure 3(b) shows $a_{\mathrm{Ca}_{2} \mathrm{SiO}_{4}}$ and $a_{(1 / 2) \mathrm{Ca}_{3} \mathrm{P}_{2} \mathrm{O}_{8}}$ at $1573 \mathrm{~K}$ based on equations (35) and (36). As seen in this figure, $a_{\mathrm{Ca}_{2} \mathrm{SiO}_{4}}$ and $a_{(1 / 2) \mathrm{Ca}_{3} \mathrm{P}_{2} \mathrm{O}_{8}}$ within $\left\langle C_{2} S-C_{3} P\right\rangle s s$ were proportional to $(1-Y)$ and $Y$, respectively. Figure 3(a) is the redrawn pseudo-binary phase diagram of $\mathrm{Ca}_{2} \mathrm{SiO}_{4}-\mathrm{Ca}_{3} \mathrm{P}_{2} \mathrm{O}_{8}$, in which compositions are shown by the values for $Y$. According to the Condensed Phase Rule, the activities were constant within the two-

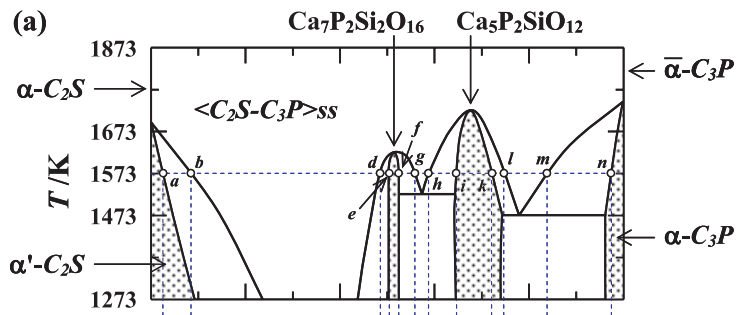

(b)

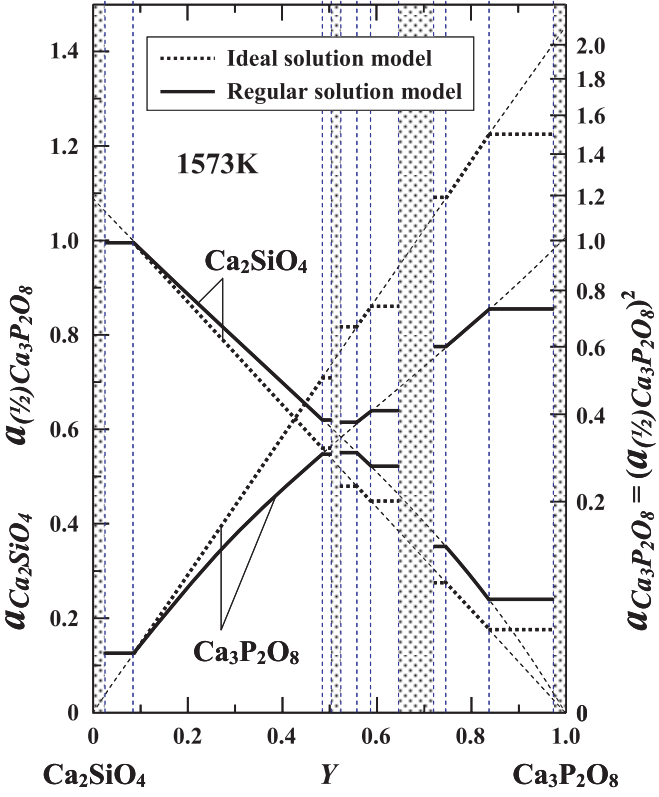

Fig. 3: (a) Phase diagram of the pseudo-binary system $\mathrm{Ca}_{2} \mathrm{SiO}_{4}{ }^{-}$ $\mathrm{Ca}_{3} \mathrm{P}_{2} \mathrm{O}_{8}$. (b) Activities of $\mathrm{Ca}_{2} \mathrm{SiO}_{4}$ and $\mathrm{Ca}_{3} \mathrm{P}_{2} \mathrm{O}_{8}$ as functions of the substitution ratio $Y$. phase regions of $a-b, d-e, f-g, h-i, k-l$ and $m-n$. The values for $a_{\mathrm{Ca}_{3} \mathrm{P}_{2} \mathrm{O}_{8}}$ were obtainable from equation (37) and could be read off by using the subsidiary scale added to Figure 3(b). Table 1 summarizes $a_{\mathrm{Ca}_{2} \mathrm{SiO}_{4}}$ and $a_{\mathrm{Ca}_{3} \mathrm{P}_{2} \mathrm{O}_{8}}$ at compositions $b, h, l$ and $m$. As seen in Table 1 , the values for $a_{\mathrm{Ca}_{3} \mathrm{P}_{2} \mathrm{O}_{8}}$ at points $h, l$ and $m$ did not satisfy inequalities (25), (26) and (21), respectively. These results led to the conclusion that the ideal solution model could not give the relative partial molar Gibbs free energies of the components within $\left\langle C_{2} S-C_{3} P\right\rangle s s$.

On the other hand, the regular solution model gave the following equations by combining equations (6), (7), (8) and (9).

$$
\begin{aligned}
\log {a_{\mathrm{Ca}_{2} \mathrm{SiO}_{4}}=} & 3.76 \times 10^{-2}+\log (1-Y) \\
& +3.32 \times 10^{-5} \times \Omega Y^{2}
\end{aligned}
$$

$$
\begin{aligned}
\log {a_{C a_{3} \mathrm{P}_{2} \mathrm{O}_{8}}=} & 2 \log a_{(1 / 2) \mathrm{Ca}_{3} \mathrm{P}_{2} \mathrm{O}_{8}} \\
= & 3.24 \times 10^{-6} \times \Delta \mathrm{H}^{\mathrm{o}}\left(\mathrm{C}_{t} \mathrm{Ca}_{3} \mathrm{O}_{8}\right)+2 \log Y \\
& +6.64 \times 10^{-5} \times \Omega(1-\mathrm{Y})^{2}
\end{aligned}
$$

These formulae included undetermined parameters, viz., $\Delta H^{\circ}{ }_{t}\left(\mathrm{Ca}_{3} \mathrm{P}_{2} \mathrm{O}_{8}\right)$ and $\Omega$. Inserting equations (38) and (39) into equation (30), the relation between $\Delta \mathrm{HH}^{\circ}\left(\mathrm{Ca}_{3} \mathrm{P}_{2} \mathrm{O}_{8}\right)$ and $\Omega$ was obtained as

$$
\Omega=5.86 \times 10^{3}-5.79 \times 10^{-2} \times \Delta H^{\circ}{ }_{t}\left(\mathrm{Ca}_{3} \mathrm{P}_{2} \mathrm{O}_{8}\right)
$$

Substituting equation (40) into equations (38) and (39), the activities of $\mathrm{Ca}_{2} \mathrm{SiO}_{4}$ and $\mathrm{Ca}_{3} \mathrm{P}_{2} \mathrm{O}_{8}$ could be expressed as functions of $\Delta \mathrm{H}^{\circ}{ }_{t}\left(\mathrm{Ca}_{3} \mathrm{P}_{2} \mathrm{O}_{8}\right)$ and $\mathrm{Y}$.

$$
\begin{aligned}
& \log a_{\mathrm{Ca}_{2} \mathrm{SiO}_{4}}=3.76 \times 10^{-2}+\log (1-\mathrm{Y})+\left[1.95 \times 10^{-1}\right. \\
& \left.-1.92 \times 10^{-6} \times \Delta H^{\circ}{ }_{t}\left(\mathrm{Ca}_{3} \mathrm{P}_{2} \mathrm{O}_{8}\right)\right] \times Y^{2}
\end{aligned}
$$

$\log a_{C a_{3} \mathrm{P}_{2} \mathrm{O}_{8}}=2 \log a_{(1 / 2) \mathrm{Ca}_{3} \mathrm{P}_{2} \mathrm{O}_{8}}$

$$
\begin{aligned}
= & 3.24 \times 10^{-6} \times \Delta H^{\circ}{ }_{t}\left(\mathrm{Ca}_{3} \mathrm{P}_{2} \mathrm{O}_{8}\right)+2 \log \mathrm{Y} \\
& +\left[3.90 \times 10^{-1}-3.84 \times 10^{-6} \times \Delta H^{\circ}{ }_{t}\left(\mathrm{Ca}_{3} \mathrm{P}_{2} \mathrm{O}_{8}\right)\right] \\
& \times(1-Y)^{2}
\end{aligned}
$$

Under the conditions that the values calculated from equations (41) and (42) satisfied inequalities (20), (21), (25) and (26), $\Delta \mathrm{H}^{\circ}{ }_{t}\left(\mathrm{Ca}_{3} \mathrm{P}_{2} \mathrm{O}_{8}\right)$ was determined as

$$
\Delta H^{\circ}{ }_{t}\left(\mathrm{Ca}_{3} \mathrm{P}_{2} \mathrm{O}_{8}\right) / \mathrm{J} \cdot \mathrm{mol}^{-1}=(2.10 \pm 2.10) \times 10^{3}
$$

Inserting equation (43) to equation (40), we had

$$
\Omega / \mathrm{J} \cdot \mathrm{mol}^{-1}=(5.74 \pm 0.12) \times 10^{3}
$$

Combining equations (38), (39), (43) and (44), the activities of $\mathrm{Ca}_{2} \mathrm{SiO}_{4}$ and $\mathrm{Ca}_{3} \mathrm{P}_{2} \mathrm{O}_{8}$ at $1573 \mathrm{~K}$ were expressed as 


\begin{tabular}{|c|c|c|c|c|c|c|c|}
\hline Region & $\begin{array}{l}Y \text { in } \\
\left\langle C_{2} S-C_{3} P\right\rangle s S\end{array}$ & $a_{\mathrm{Ca}_{2} \mathrm{SiO}_{4}}$ & $a_{\mathrm{Ca}_{3} \mathrm{P}_{2} \mathrm{O}_{8}}$ & $\log a_{C a O}$ & $\log a_{\mathrm{SiO}_{2}}$ & $\log a_{P_{2} \mathrm{O}_{5}}$ & Remark \\
\hline $\begin{array}{l}\left\langle C_{2} S-C_{3} P\right\rangle S S+\mathrm{Ca}_{2} \mathrm{SiO}_{4}+ \\
\mathrm{Ca}_{3} \mathrm{SiO}_{5} \\
\text { (triangle } b-a-\mathrm{Ca}_{3} \mathrm{SiO}_{5} \text { ) } \\
\end{array}$ & 0.088 & $\begin{array}{l}0.998^{\mathrm{a})} \pm \\
0.000\end{array}$ & $\begin{array}{l}0.016 \pm \\
0.000\end{array}$ & $\begin{array}{l}-0.02 \pm \\
0.00\end{array}$ & $\begin{array}{l}-4.74 \pm \\
0.00\end{array}$ & $-26.53^{a)}$ & $\begin{array}{l}\log a_{P_{2} \mathrm{O}_{5}}=-26.53 ; \\
\text { Eq. (28) } \\
a_{\mathrm{Ca}_{2} \mathrm{SiO}_{4}}<1 \text {; Eq. (20) }\end{array}$ \\
\hline $\begin{array}{l}\left\langle C_{2} S-C_{3} P\right\rangle s S+C a O+ \\
C_{3} \mathrm{SiO}_{5} \\
\text { (triangle } c-\mathrm{CaO}-\mathrm{Ca}_{3} \mathrm{SiO}_{5} \text { ) }\end{array}$ & $\begin{array}{l}0.131 \pm \\
0.000\end{array}$ & $\begin{array}{l}0.955 \pm \\
0.000\end{array}$ & $\begin{array}{l}0.034 \pm \\
0.000\end{array}$ & 0.00 & -4.80 & $\begin{array}{l}-26.27 \pm \\
0.00\end{array}$ & - \\
\hline $\begin{array}{l}\left\langle C_{2} S-C_{3} P\right\rangle S S+\mathrm{CaO}+ \\
\mathrm{Ca}_{7} \mathrm{P}_{2} \mathrm{Si}_{2} \mathrm{O}_{16} \\
\text { (triangle } d-\mathrm{CaO}-e \text { ) }\end{array}$ & 0.493 & $\begin{array}{l}0.615 \pm \\
0.001\end{array}$ & $\begin{array}{l}0.309 \pm \\
0.003\end{array}$ & 0.00 & $\begin{array}{l}-4.99 \pm \\
0.00\end{array}$ & $\begin{array}{l}-25.31 \pm \\
0.00\end{array}$ & - \\
\hline $\begin{array}{l}\left\langle C_{2} S-C_{3} P\right\rangle s S+\mathrm{CaO}+ \\
\mathrm{Ca}_{7} \mathrm{P}_{2} \mathrm{Si}_{2} \mathrm{O}_{16} \\
\text { (triangle } g-\mathrm{CaO}-f \text { ) }\end{array}$ & 0.560 & $\begin{array}{l}0.550 \pm \\
0.001\end{array}$ & $\begin{array}{l}0.378 \pm \\
0.005\end{array}$ & 0.00 & $\begin{array}{l}-5.04 \pm \\
0.00\end{array}$ & $\begin{array}{l}-25.22 \pm \\
0.01\end{array}$ & - \\
\hline $\begin{array}{l}\left\langle C_{2} S-C_{3} P\right\rangle S S+\mathrm{CaO}+ \\
\mathrm{Ca}_{5} \mathrm{P}_{2} \mathrm{SiO}_{12} \\
\text { (triangle } h-\mathrm{CaO}-i \text { ) }\end{array}$ & 0.592 & $\begin{array}{l}0.519 \pm \\
0.001\end{array}$ & $\begin{array}{l}0.412^{\mathrm{a})} \pm \\
0.005\end{array}$ & 0.00 & $\begin{array}{l}-5.06 \pm \\
0.01\end{array}$ & $\begin{array}{l}-25.19 \pm \\
0.01\end{array}$ & $\begin{array}{l}a_{\mathrm{Ca}_{3} \mathrm{P}_{2} \mathrm{O}_{8}}<0.417 ; \mathrm{Eq} . \\
(25)\end{array}$ \\
\hline $\begin{array}{l}\left\langle C_{2} S-C_{3} P\right\rangle S S+\mathrm{Ca}_{4} \mathrm{P}_{2} \mathrm{O}_{9}+ \\
\mathrm{Ca}_{5} \mathrm{P}_{2} \mathrm{SiO}_{12} \\
\left.\text { (triangle } l-\mathrm{Ca}_{4} \mathrm{P}_{2} \mathrm{O}_{9}-k\right) \\
\end{array}$ & 0.748 & $\begin{array}{l}0.351 \pm \\
0.002\end{array}$ & $\begin{array}{l}0.602^{\mathrm{a})} \pm \\
0.008\end{array}$ & $\begin{array}{l}-0.16 \pm \\
0.01\end{array}$ & $\begin{array}{l}-4.92 \pm \\
0.01\end{array}$ & $\begin{array}{l}-24.54 \pm \\
0.02\end{array}$ & $\begin{array}{l}0.417<a_{\mathrm{Ca}_{3} \mathrm{P}_{2} \mathrm{O}_{8}}<1 \text {; } \\
\text { Eq. (26) }\end{array}$ \\
\hline $\begin{array}{l}\left\langle C_{2} S-C_{3} P\right\rangle S S+\mathrm{Ca}_{4} \mathrm{P}_{2} \mathrm{O}_{9}+ \\
\mathrm{Ca}_{3} \mathrm{P}_{2} \mathrm{O}_{8} \\
\text { (triangle } m-\mathrm{Ca}_{4} \mathrm{P}_{2} \mathrm{O}_{9}-n \text { ) }\end{array}$ & 0.841 & $\begin{array}{l}0.236 \pm \\
0.001\end{array}$ & $\begin{array}{l}0.735^{\mathrm{a})} \pm \\
0.011\end{array}$ & $\begin{array}{l}-0.25 \pm \\
0.01\end{array}$ & $\begin{array}{l}-4.91 \pm \\
0.01\end{array}$ & $\begin{array}{l}-24.19 \pm \\
0.02\end{array}$ & $a_{\mathrm{Ca}_{3} \mathrm{P}_{2} \mathrm{O}_{8}}<1$; Eq. (21) \\
\hline
\end{tabular}

a) The values with superscript "a" satisfied the necessary conditions.

Table 2: Calculation results of the regular solution model with $\Delta H^{\circ}{ }_{t}\left(\mathrm{Ca}_{3} \mathrm{P}_{2} \mathrm{O}_{8}\right)=2.10 \pm 2.10 \mathrm{~kJ} \cdot \mathrm{mol}^{-1}$ and $\Omega=5.74 \pm 0.12 \mathrm{~kJ} \cdot \mathrm{mol}^{-1}$.

$$
\begin{aligned}
\log a_{\mathrm{Ca}_{2} \mathrm{SiO}_{4}}= & 3.76 \times 10^{-2}+\log (1-Y)+1.91 \times 10^{-1} \times Y^{2} \\
\log {a_{C a_{3} P_{2} O_{8}}=} & 2 \log a_{(1 / 2) C_{3} \mathrm{P}_{2} \mathrm{O}_{8}}=6.80 \times 10^{-3}+2 \log Y \\
& +3.81 \times 10^{-1} \times(1-Y)^{2}
\end{aligned}
$$

Table 2 gives the present values for $a_{\mathrm{Ca}_{2} \mathrm{SiO}_{4}}$ and $a_{\mathrm{Ca}_{3} \mathrm{P}_{2} \mathrm{O}_{8}}$ calculated from equations (45) and (46). The uncertainties of the activities in Table 2 were based on the inaccuracies of $\Delta \mathrm{H}^{\circ}{ }_{t}\left(\mathrm{Ca}_{3} \mathrm{P}_{2} \mathrm{O}_{8}\right)$ and $\Omega$ given in equations (43) and (44). As seen in this table, inequalities (20), (25), (26) and (21) held with the present results at compositions $b, h, l$ and $m$, respectively. Solid curves in Figure 3(b) represent the activity-composition curves evaluated from equations (45) and (46). These curves were slightly convex upward owing to the positive value for the interaction parameter $\Omega$. As already mentioned above, the activities were constant in the two-phase regions. For example, the $\mathrm{Ca}_{3} \mathrm{P}_{2} \mathrm{O}_{8}$ activity at point $h$ was equal to that at point $i$. The hatched areas in Figure 3 denote the composition ranges of non-stoichiometric compounds of $\alpha^{\prime}-\mathrm{Ca}_{2} \mathrm{SiO}_{4}, \mathrm{Ca}_{7} \mathrm{P}_{2} \mathrm{Si}_{2} \mathrm{O}_{16}$, $\mathrm{Ca}_{5} \mathrm{P}_{2} \mathrm{SiO}_{12}$ and $\alpha-\mathrm{Ca}_{3} \mathrm{P}_{2} \mathrm{O}_{8}$, in which activity-composition curves could not be obtained in this study.

\section{Discussion}

Figure 4(a) shows the iso-thermal section of the ternary system $\mathrm{CaO}-\mathrm{SiO}_{2}-\mathrm{P}_{2} \mathrm{O}_{5}$ near the $\mathrm{CaO}$ apex at $1573 \mathrm{~K}$; this figure is identical to Figure 1(a). By using the present results of the regular solution model, the activities of $\mathrm{CaO}$, $\mathrm{SiO}_{2}$ and $\mathrm{P}_{2} \mathrm{O}_{5}$ could be calculated within the following regions.

$$
\begin{aligned}
& \left\langle C_{2} S-C_{3} P\right\rangle s S+\mathrm{Ca}_{2} \mathrm{SiO}_{4}+\mathrm{Ca}_{3} \mathrm{SiO}_{5} \text {; triangle } b-a-\mathrm{Ca}_{3} \mathrm{SiO}_{5} \\
& \left\langle C_{2} S-C_{3} P\right\rangle S S+\mathrm{Ca}_{3} \mathrm{SiO}_{5} \text {; region } b-c-\mathrm{Ca}_{3} \mathrm{SiO}_{5} \\
& \left\langle C_{2} S-C_{3} P\right\rangle s S+\mathrm{CaO}+\mathrm{Ca}_{3} \mathrm{SiO}_{5} \text {; triangle } c-\mathrm{CaO}-\mathrm{Ca}_{3} \mathrm{SiO}_{5} \\
& \left\langle C_{2} S-C_{3} P\right\rangle s S+\mathrm{CaO} \text {; region } c-d-\mathrm{CaO} \\
& \left\langle C_{2} S-C_{3} P\right\rangle s S+\mathrm{CaO}+\mathrm{Ca}_{7} \mathrm{P}_{2} \mathrm{Si}_{2} \mathrm{O}_{16} \text {; triangle } d \text {-CaO-e } \\
& \left\langle C_{2} S-C_{3} P\right\rangle s S+\mathrm{CaO}+\mathrm{Ca}_{7} \mathrm{P}_{2} \mathrm{Si}_{2} \mathrm{O}_{16} \text {; triangle g-CaO-f } \\
& \left\langle C_{2} S-C_{3} P\right\rangle s S+\mathrm{CaO} \text {; region } g-h-\mathrm{CaO} \\
& \left\langle C_{2} S-C_{3} P\right\rangle s S+\mathrm{CaO}+\mathrm{Ca}_{5} \mathrm{P}_{2} \mathrm{SiO}_{12} \text {; triangle } h-\mathrm{CaO}-i \\
& \left\langle C_{2} S-C_{3} P\right\rangle s S+\mathrm{Ca}_{4} \mathrm{P}_{2} \mathrm{O}_{9}+\mathrm{Ca}_{5} \mathrm{P}_{2} \mathrm{SiO}_{12} \text {; triangle } l-\mathrm{Ca}_{4} \mathrm{P}_{2} \mathrm{O}_{9}-k
\end{aligned}
$$


(a)
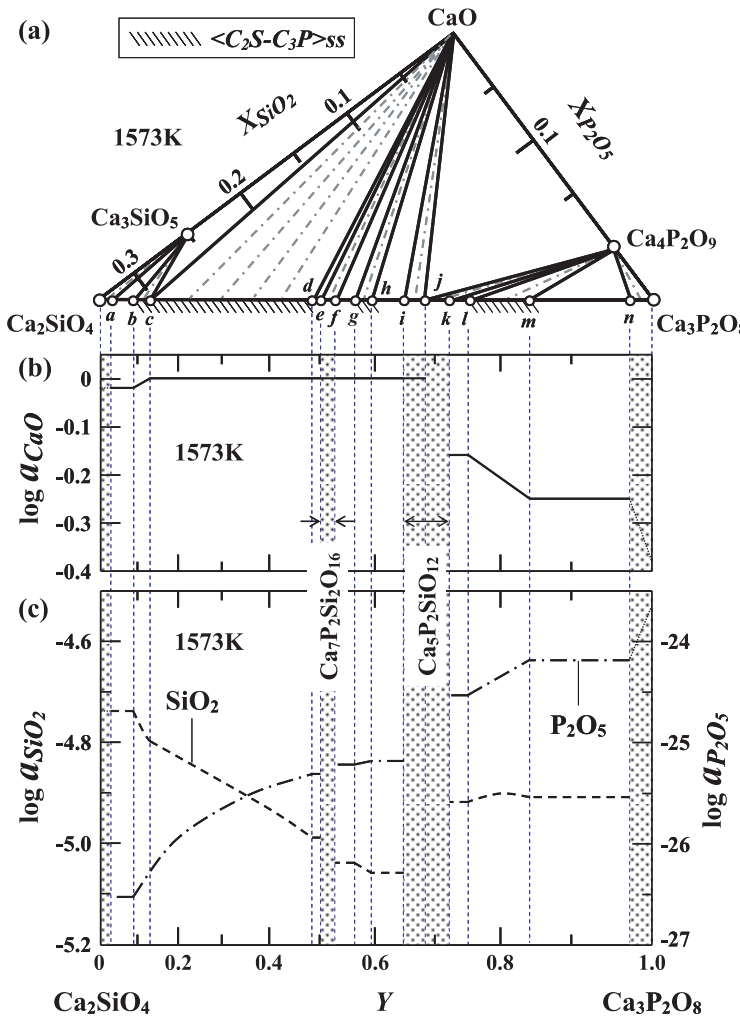

Fig. 4: (a) Iso-thermal section of the ternary system $\mathrm{CaO}-\mathrm{SiO}_{2}-\mathrm{P}_{2} \mathrm{O}_{5}$ near the $\mathrm{CaO}$ apex at $1573 \mathrm{~K}$. (b) Activities of $\mathrm{CaO}$ at $1573 \mathrm{~K}$. (c) Activities of $\mathrm{SiO}_{2}$ and $\mathrm{P}_{2} \mathrm{O}_{5}$ at $1573 \mathrm{~K}$.

$$
\left\langle C_{2} S-C_{3} P\right\rangle s S+\mathrm{Ca}_{4} \mathrm{P}_{2} \mathrm{O}_{9} ; \text { region } l-m-\mathrm{Ca}_{4} \mathrm{P}_{2} \mathrm{O}_{9}
$$$$
\left\langle C_{2} S-C_{3} P\right\rangle s s+\mathrm{Ca}_{4} \mathrm{P}_{2} \mathrm{O}_{9}+\mathrm{Ca}_{3} \mathrm{P}_{2} \mathrm{O}_{8} \text {; triangle } m-\mathrm{Ca}_{4} \mathrm{P}_{2} \mathrm{O}_{9}-n
$$

Such regions could be classified by solid phases coexisting with $\left\langle C_{2} S-C_{3} P\right\rangle s s, v i z$., $\mathrm{Ca}_{3} \mathrm{SiO}_{5}, \mathrm{CaO}$ and $\mathrm{Ca}_{4} \mathrm{P}_{2} \mathrm{O}_{9}$.

In the regions including $\mathrm{Ca}_{3} \mathrm{SiO}_{5}$, the activity of $\mathrm{Ca}_{3} \mathrm{SiO}_{5}$ should be unity. Therefore, equation (13) could be rewritten as

$$
\log K(11)=-3 \log a_{\mathrm{CaO}}-\log a_{\mathrm{SiO}_{2}}
$$

Solving simultaneous equations (12), (16) and (47), we had

$$
\begin{aligned}
\log a_{\mathrm{CaO}}= & -\log a_{\mathrm{Ca}_{2} \mathrm{SiO}_{4}}+\log K(10)-\log K(11) \\
\log a_{\mathrm{SiO}_{2}}= & 3 \log a_{\mathrm{Ca}_{2} \mathrm{SiO}_{4}}-3 \log K(10)+2 \log K(11) \\
\log {a_{\mathrm{P}_{2} \mathrm{O}_{5}}}= & \log a_{\mathrm{Ca}_{3} \mathrm{P}_{2} \mathrm{O}_{8}}+3 \log a_{\mathrm{Ca}_{2} \mathrm{SiO}}-3 \log K(10) \\
& +3 \log K(11)-\log K(14)
\end{aligned}
$$

Combining equations (45), (46), (48), (49) and (50), the activities of $\mathrm{CaO}, \mathrm{SiO}_{2}$ and $\mathrm{P}_{2} \mathrm{O}_{5}$ at $1573 \mathrm{~K}$ in the two-phase region of $\left\langle C_{2} S-C_{3} P\right\rangle s S+\mathrm{Ca}_{3} \mathrm{SiO}_{5}$ (region $b-c-\mathrm{Ca}_{3} \mathrm{SiO}_{5}$ ) could be expressed as the functions of $Y$.

$$
\begin{aligned}
\log a_{C a 0} & =-0.06-\log (1-Y)-1.91 \times 10^{-1} \times Y^{2} \\
\log a_{S_{i O}} & =-4.63+3 \log (1-Y)+5.73 \times 10^{-1} \times Y^{2} \\
\log a_{P_{2} O_{5}}= & -24.62+3 \log (1-Y)+2 \log Y+5.73 \times 10^{-1} \times Y^{2} \\
& +3.81 \times 10^{-1} \times(1-Y)^{2}
\end{aligned}
$$

The activities in the three-phase region of $\left\langle C_{2} S-C_{3} P\right\rangle s S+$ $\mathrm{Ca}_{2} \mathrm{SiO}_{4}+\mathrm{Ca}_{3} \mathrm{SiO}_{5}$ (triangle $b$ - $a-\mathrm{Ca}_{3} \mathrm{SiO}_{5}$ ) could be calculated by inserting $Y=0.088$ at point $b$ into equations (51), (52) and (53).

$$
\begin{aligned}
\log a_{\text {CaO }}=-0.02 & \text { (at point } b ; Y=0.088, T=1573 \mathrm{~K}) \\
\log a_{\mathrm{SiO}_{2}}=-4.74 & \text { (at point } b ; Y=0.088, T=1573 \mathrm{~K}) \\
\log {a_{P_{2} \mathrm{O}_{5}}}=-26.53 & \text { (at point } b ; Y=0.088, T=1573 \mathrm{~K})
\end{aligned}
$$

On the other hand, the composition of $\left\langle C_{2} S-C_{3} P\right\rangle$ ss in equilibrium with $\mathrm{Ca}_{3} \mathrm{SiO}_{5}$ and $\mathrm{CaO}$, i.e., point $c$, has not been reported. By solving equation (51) under the condition that $\log a_{C a O}=0$, this composition could be estimated as

$$
Y=0.131 \quad \text { (at point } c, T=1573 \mathrm{~K} \text { ) }
$$

Inserting equation (57) to equations (52) and (53), the $\mathrm{SiO}_{2}$ and $\mathrm{P}_{2} \mathrm{O}_{5}$ activities in the three-phase assemblage of $\left\langle C_{2} S-C_{3} P\right\rangle S S+\mathrm{CaO}+\mathrm{Ca}_{3} \mathrm{SiO}_{5}$ (triangle $c$ - $\mathrm{CaO}-\mathrm{Ca}_{3} \mathrm{SiO}_{5}$ ) were obtained as

$$
\begin{array}{r}
\left.\log a_{S_{i O_{2}}}=-4.80 \quad \text { (at point } c ; Y=0.131, T=1573 \mathrm{~K}\right) \\
\left.\log a_{P_{2} O_{5}}=-26.27 \quad \text { (at point } c ; Y=0.131, T=1573 \mathrm{~K}\right)
\end{array}
$$

The $\mathrm{CaO}$ activity in the regions including $\mathrm{CaO}$ should be unity. Thus, equations (12) and (16), respectively, could be rewritten as

$$
\begin{aligned}
& \log a_{\mathrm{SiO}_{2}}=\log a_{\mathrm{Ca}_{2} \mathrm{SiO}_{4}}-\log K(10) \\
& \log a_{\mathrm{P}_{2} \mathrm{O}_{5}}=\log a_{\mathrm{Ca}_{3} \mathrm{P}_{2} \mathrm{O}_{8}}-\log K(14)
\end{aligned}
$$

Combining equations (45), (46), (60) and (61), the $\mathrm{SiO}_{2}$ and $\mathrm{P}_{2} \mathrm{O}_{5}$ activities within the two-phase resion of $\left\langle C_{2} S-C_{3} P\right\rangle$ ss + $\mathrm{CaO}$ (regions $c-d-\mathrm{CaO}$ and $g-h-\mathrm{CaO}$ ) were given as

$$
\begin{gathered}
\log a_{\mathrm{SiO}_{2}}=-4.74+\log (1-Y)+1.91 \times 10^{-1} \times Y^{2} \\
\log a_{P_{2} O_{5}}=-24.79+2 \log Y+3.81 \times 10^{-1} \times(1-Y)^{2}
\end{gathered}
$$

The values for $a_{\mathrm{SiO}_{2}}$ and $a_{\mathrm{P}_{2} \mathrm{O}_{5}}$ in the three-phase regions of $\left\langle C_{2} S-C_{3} P\right\rangle S S+\mathrm{CaO}+\mathrm{Ca}_{7} \mathrm{P}_{2} \mathrm{Si}_{2} \mathrm{O}_{16}$ (triangles $d$-CaO-e and $g$-CaO-f) and $\left\langle C_{2} S-C_{3} P\right\rangle s S+\mathrm{CaO}+\mathrm{Ca}_{5} \mathrm{P}_{2} \mathrm{SiO}_{12}$ (triangle $h$-CaO-i) could be calculated from equations (62) and (63). 
Based on the unit $\mathrm{Ca}_{4} \mathrm{P}_{2} \mathrm{O}_{9}$ activity in the regions including $\mathrm{Ca}_{4} \mathrm{P}_{2} \mathrm{O}_{9}$, equation (19) was rewritten as

$$
\log K(17)=-4 \log a_{C a O}-\log a_{P_{2} O_{5}}
$$

Solving simultaneous equations (12), (16) and (64), we had

$$
\begin{aligned}
& \log a_{\mathrm{CaO}}=-\log a_{\mathrm{Ca}_{3} \mathrm{P}_{2} \mathrm{O}_{8}}+\log K(14)-\log K(17) \\
& \log a_{\mathrm{SiO}_{2}}=\log a_{\mathrm{Ca}_{2} \mathrm{SiO}_{4}}+2 \log a_{\mathrm{Ca}_{3} \mathrm{P}_{2} \mathrm{O}_{8}}-\log K(10) \\
& -2 \log K(14)+2 \log K(17) \\
& \log a_{P_{2} O_{5}}=4 \log a_{C a_{3} P_{2} O_{8}}-4 \log K(14)+3 \log K(17)
\end{aligned}
$$

Combining equations (45), (46), (65), (66) and (67), the activities at $1573 \mathrm{~K}$ in the two-phase region of $\left\langle C_{2} S-C_{3} P\right\rangle s S+$ $\mathrm{Ca}_{4} \mathrm{P}_{2} \mathrm{O}_{9}$ (region $l-m-\mathrm{Ca}_{4} \mathrm{P}_{2} \mathrm{O}_{9}$ ) could be expressed as

$$
\begin{gathered}
\log a_{C a O}=-0.39-2 \log Y-3.81 \times 10^{-1} \times(1-Y)^{2} \\
\log a_{\mathrm{SiO}_{2}}=-3.97+\log (1-Y)+4 \log Y+1.91 \times 10^{-1} \times Y^{2} \\
+7.62 \times 10^{-1} \times(1-Y)^{2} \\
\log a_{P_{2} O_{5}}=-23.63+8 \log Y+1.52 \times(1-Y)^{2}
\end{gathered}
$$

The values for the activities in the three-phase regions of $\left\langle C_{2} S-C_{3} P\right\rangle S S+\mathrm{Ca}_{4} \mathrm{P}_{2} \mathrm{O}_{9}+\mathrm{Ca}_{5} \mathrm{P}_{2} \mathrm{SiO}_{12}$ (triangle $l-\mathrm{Ca}_{4} \mathrm{P}_{2} \mathrm{O}_{9}-k$ ) and $\left\langle C_{2} S-C_{3} P\right\rangle s s+\mathrm{Ca}_{4} \mathrm{P}_{2} \mathrm{O}_{9}+\mathrm{Ca}_{3} \mathrm{P}_{2} \mathrm{O}_{8}$ (triangle $m-\mathrm{Ca}_{4} \mathrm{P}_{2} \mathrm{O}_{9}-n$ ) could be calculated from equations (68), (69) and (70).

The $\mathrm{CaO}, \mathrm{SiO}_{2}$ and $\mathrm{P}_{2} \mathrm{O}_{5}$ activities estimated in this study are summarized in Table 2, and illustrated in Figures 4(b) and 4(c). The uncertainties of the values in Table 2 were due to the inaccuracies of $\Delta \mathrm{H}^{\circ}{ }_{t}\left(\mathrm{Ca}_{3} \mathrm{P}_{2} \mathrm{O}_{8}\right)$ and $\Omega$ determined in this study. Figure 4(b) shows that the $\mathrm{CaO}$ activities are unity between point $c$ and point $j$; in this composition range, the two- and three-phase regions include solid $\mathrm{CaO}$ as seen in Figure 4(a). Figure 4(c) illustrates that the $\mathrm{P}_{2} \mathrm{O}_{5}$ activities increase monotonically with an increase in the values for $Y$ in $\left\langle C_{2} S-C_{3} P\right\rangle$ ss. It would be worth mentioning here that the $\mathrm{P}_{2} \mathrm{O}_{5}$ activity in the two-phase assemblage of stoichiometric $\mathrm{Ca}_{3} \mathrm{P}_{2} \mathrm{O}_{8}+\mathrm{Ca}_{4} \mathrm{P}_{2} \mathrm{O}_{9}$ at $1573 \mathrm{~K}$ can be calculated as

$$
\begin{aligned}
\log a_{P_{2} \mathrm{O}_{5}} & =-4 \log K(14)+3 \log K(17) \\
& =-23.66 \text { at } 1573 \mathrm{~K}
\end{aligned}
$$

This value corresponds to the logarithmic activity of $\mathrm{P}_{2} \mathrm{O}_{5}$ at $Y=1.0$ in Figure 4(c), and would not be imcompatible with the activity-composition curves determined in this study. On the other hand, the $\mathrm{SiO}_{2}$ activities do not decrease monotonically with an increase in $Y$. Magnitude correlations of activities strongly depend on phase rela- tions. Therefore, the behaviour of the $\mathrm{SiO}_{2}$ and $\mathrm{P}_{2} \mathrm{O}_{5}$ activities will be able to be explained by future work on the $\mathrm{SiO}_{2}$-rich and/or $\mathrm{P}_{2} \mathrm{O}_{5}$-rich areas of the $\mathrm{CaO}-\mathrm{SiO}_{2}-\mathrm{P}_{2} \mathrm{O}_{5}$ ternary iso-thermal section. The present values for $a_{P_{2} O_{5}}$ and $a_{\mathrm{SiO}_{2}}$ can be recommended at least as tentative estimates for understanding dephosphorization process.

The reaction of phosphorus removal from molten iron can be represented as

$$
2[\mathrm{P}]_{\mathrm{Fe}}+5(\mathrm{FeO})_{\text {slag }}=\left(\mathrm{P}_{2} \mathrm{O}_{5}\right)_{\text {slag }}+5\{\mathrm{Fe}\}
$$

where $[\mathrm{P}]_{\mathrm{Fe}}$ is phosphorus in liquid iron, $(\mathrm{FeO})_{\text {slag }}$ and $\left(\mathrm{P}_{2} \mathrm{O}_{5}\right)_{\text {slag }}$ are $\mathrm{FeO}$ and $\mathrm{P}_{2} \mathrm{O}_{5}$ in liquid slag, and $\{\mathrm{Fe}\}$ is liquid iron. For reaction (72), Turkdogan and Pearson derived the following expression $/ 10 /$.

$$
\log K(72)=\log \left\{a_{P_{2} O_{5}} / h_{P}^{2} a_{\mathrm{FeO}}^{5}\right\}=-17.7+8,490 /(T / \mathrm{K})
$$

By rewriting equation (73), we have

$\log h_{P}=-(1 / 2) \log K(72)+(1 / 2) \log a_{P_{2} O_{5}}-(5 / 2) \log a_{F e O}$

For carbon-saturated $\{\mathrm{Fe}-\mathrm{C}-\mathrm{P}\}$ liquid alloys, the Henrian activity of phosphorus is given by

$$
\log h_{P}=\log [\% P]+e_{P}^{C}[\% C]
$$

By combining equations (74) and (75), we have

$$
\begin{aligned}
\log [\% P]= & -e_{P}^{C}[\% C]-(1 / 2) \log K(72)+(1 / 2) \log a_{P_{2} O_{5}} \\
& -(5 / 2) \log a_{F e O} \\
= & -e_{P}^{C}[\% C]+(1 / 2) \log a_{P_{2} O_{5}} \\
& -(5 / 2) \log a_{F e O}+8.9-4,250 /(T / K)
\end{aligned}
$$

Equation (76) means that the equilibrium phosphorus concentrations can be estimated by using the values for the activities of $\mathrm{P}_{2} \mathrm{O}_{5}$ and $\mathrm{FeO}$. Figure 5 shows a schematic illustration of the iso-thermal tetrahedron of the pseudoquaternary system $\mathrm{CaO}-\mathrm{Ca}_{2} \mathrm{SiO}_{4}-\mathrm{Ca}_{3} \mathrm{P}_{2} \mathrm{O}_{8}-\mathrm{FeO}$ at $1573 \mathrm{~K}$, showing the following four-phase assemblages $/ 11 /$.

$$
\begin{gathered}
\mathrm{Ca}_{3} \mathrm{SiO}_{5}+\mathrm{Ca}_{2} \mathrm{SiO}_{4}+\left\langle C_{2} S-C_{3} P\right\rangle s S+\text { Liquid; tetrahedron } \\
\mathrm{Ca}_{3} \mathrm{SiO}_{5}-a-b-L(1) \\
\mathrm{CaO}+\mathrm{Ca}_{3} \mathrm{SiO}_{5}+\left\langle C_{2} \mathrm{~S}-C_{3} P\right\rangle s \mathrm{SS}+\text { Liquid; tetrahedron } \\
\mathrm{CaO}-\mathrm{Ca}_{3} \mathrm{SiO}_{5}-\mathrm{C}-L(2) \\
\mathrm{CaO}+\mathrm{Ca}_{4} \mathrm{P}_{2} \mathrm{O}_{9}+\mathrm{Ca}_{5} \mathrm{P}_{2} \mathrm{SiO}_{12}+\text { Liquid; tetrahedron } \\
\mathrm{CaO}-\mathrm{Ca}_{4} \mathrm{P}_{2} \mathrm{O}_{9}-\mathrm{j}-L(3)
\end{gathered}
$$

According to the Condensed Phase Rule, when four phases coexist in a four-component system, there is only one 


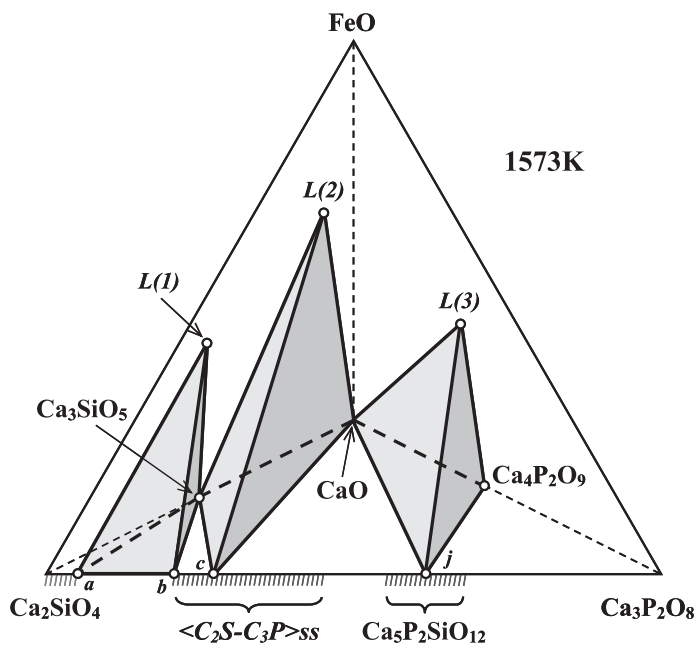

Fig. 5: Schematic illustration of the iso-thermal tetrahedron showing the phase relations in the pseudo-quaternary system $\mathrm{CaO}-\mathrm{Ca}_{2} \mathrm{SiO}_{4}-$ $\mathrm{Ca}_{3} \mathrm{P}_{2} \mathrm{O}_{9}-\mathrm{FeO}$ coexisitng with metallic iron at $1573 \mathrm{~K}$.

degree of freedom. This implies that for a particular temperature, the activities of $\mathrm{FeO}$ and $\mathrm{P}_{2} \mathrm{O}_{5}$ are fixed and therefore independent of the bulk slag composition. The $\mathrm{P}_{2} \mathrm{O}_{5}$ activities in the four-phase assemblages of $\mathrm{Ca}_{3} \mathrm{SiO}_{5}+$ $\mathrm{Ca}_{2} \mathrm{SiO}_{4}+\left\langle C_{2} S-C_{3} P\right\rangle s S+$ Liquid, $\mathrm{CaO}+\mathrm{Ca}_{3} \mathrm{SiO}_{5}+\left\langle C_{2} S-C_{3} P\right\rangle s s+$ Liquid and $\mathrm{CaO}+\mathrm{Ca}_{4} \mathrm{P}_{2} \mathrm{O}_{9}+\mathrm{Ca}_{5} \mathrm{P}_{2} \mathrm{SiO}_{12}+$ Liquid are given by equations (27), (59) and (22), respectively. On the other hand, the $\mathrm{FeO}$ activities have been reported as follows $/ 11 /$.

$$
\begin{gathered}
\log a_{\mathrm{FeO}}=-0.77+720 /(T / \mathrm{K}) \\
\mathrm{Ca}_{3} \mathrm{SiO}_{5}+\mathrm{Ca}_{2} \mathrm{SiO}_{4}+\left\langle C_{2} S-C_{3} P\right\rangle s \mathrm{SS} \text { Liquid } \\
\log a_{\mathrm{FeO}}=-1.57+1,960 /(T / \mathrm{K}) \\
\mathrm{CaO}+\mathrm{Ca}_{3} \mathrm{SiO}_{5}+\left\langle C_{2} S-C_{3} P\right\rangle S S+\text { Liquid } \\
\log a_{\mathrm{FeO}}=0.90-1,810 /(T / \mathrm{K}) \\
\mathrm{CaO}+\mathrm{Ca}_{4} \mathrm{P}_{2} \mathrm{O}_{9}+\mathrm{Ca}_{5} \mathrm{P}_{2} \mathrm{SiO}_{12}+\text { Liquid }
\end{gathered}
$$

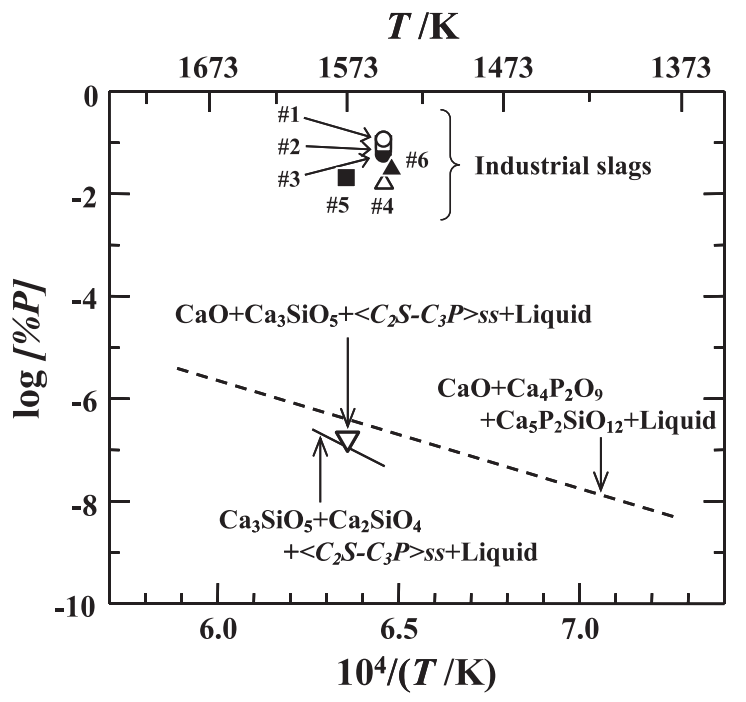

Fig. 6: Estimated phosphorus contents in molten iron.

Figure 6 shows the estimated phosphorus contents in molten iron attainable with the four-phase assemblages under consideration. This figure also gives the final phosphorus levels achieved with the industrial slags, given in Table 3/12/. It is evident from this graph that the phosphorus concentrations attainable by using the heterogeneous slags are four to five orders of magnitude lower than those obtained with the industrial slags. As a consequence of this behavior, the opportunity is available to considerably reduce required slag volume. Recently, phosphorus removal from hot metal in Japanese steelmaking industries has been operated with relatively lower basic slags to

\begin{tabular}{|c|c|c|c|c|c|c|c|c|}
\hline \multirow{2}{*}{$\begin{array}{l}\text { Sample } \\
\text { Code }\end{array}$} & \multicolumn{6}{|c|}{ Slag composition (mole \%) } & \multicolumn{2}{|c|}{ Hot metal } \\
\hline & $\mathrm{CaO}$ & $\mathrm{SiO}_{2}$ & $\mathrm{FeO}$ & $\mathrm{CaF}_{2}$ & $\mathrm{P}_{2} \mathrm{O}_{5}$ & Others* & $T / \mathrm{K}$ & {$[\% P]$} \\
\hline$\# 1$ & 53.0 & 32.2 & 1.7 & 6.8 & 1.1 & 5.3 & 1548 & 0.112 \\
\hline$\# 2$ & 57.3 & 28.3 & 2.5 & 5.6 & 1.8 & 4.5 & 1548 & 0.090 \\
\hline \#3 & 58.3 & 20.8 & 2.4 & 10.4 & 2.6 & 5.5 & 1548 & 0.057 \\
\hline$\# 4$ & 58.9 & 16.1 & 2.1 & 11.1 & 3.2 & 8.6 & 1548 & 0.016 \\
\hline \#5 & 58.3 & 11.1 & 1.6 & 21.0 & 3.4 & 4.6 & 1573 & 0.020 \\
\hline \#6 & 60.0 & 11.6 & 1.1 & 21.5 & 2.1 & 3.7 & 1543 & 0.030 \\
\hline
\end{tabular}
aim at reducing consumption of fluorspar, $\mathrm{CaF}_{2}$, which causes emission of hazardous fluoride species. The present results of solid solutions between $\mathrm{Ca}_{2} \mathrm{SiO}_{4}$ and $\mathrm{Ca}_{3} \mathrm{P}_{2} \mathrm{O}_{8}$ would also be applicable to estimate thermodynamic properties of such dephosphorization slags.

* "Others" means $\mathrm{CaS}+\mathrm{MgO}+\mathrm{MnO}+\mathrm{Al}_{2} \mathrm{O}_{3}$ 


\section{Conclusions}

Solution models have been applied to solid solutions between $\mathrm{Ca}_{2} \mathrm{SiO}_{4}$ and $\mathrm{Ca}_{3} \mathrm{P}_{2} \mathrm{O}_{8}$ to aim at deriving their thermodynamic properties at $1573 \mathrm{~K}$. The parameters included in the regular solution model were determined under the conditions that the activities of $\mathrm{Ca}_{2} \mathrm{SiO}_{4}$ and $\mathrm{Ca}_{3} \mathrm{P}_{2} \mathrm{O}_{8}$ were consistent with the literature data and the phase diagrams. The present results suggested the estimations of the activities of the components in the $\mathrm{CaO}-\mathrm{SiO}_{2}-\mathrm{P}_{2} \mathrm{O}_{5}$ ternary system at high $\mathrm{CaO}$ contents and the composition of the $\mathrm{Ca}_{2} \mathrm{SiO}_{4}-\mathrm{Ca}_{3} \mathrm{P}_{2} \mathrm{O}_{8}$ solid solution in equilibrium with $\mathrm{CaO}$ and $\mathrm{Ca}_{3} \mathrm{SiO}_{5}$ at $1573 \mathrm{~K}$.

Received: March 2, 2012. Accepted: July 10, 2012.

\section{References}

[1] M. Matsu-sue, M. Hasegawa, K. Fushi-tani and M. Iwase, Steel Res. Int., 78 (6), 465-467 (2007).
[2] W. Fix, H. Heymann and R. Heinke, J. Am. Ceram. Soc., 52 (6), 346-347 (1969). Cited from ACerS-NIST PHASE EQUILIBRIUM DIAGRAMS, CD-ROM database, Version 3.1, Figure 4563.

[3] H. Suito, Y. Hayashida and Y. Takahashi, Tetsu-to-Hagané (in Japanese), 63 (8), 1252-1259 (1977).

[4] O. Kubaschewski, C. B. Alcock and P. J. Spencer, Materials Thermochemistry, 6th edition, Pergamon Press, 1993.

[5] M. Hasegawa and M. Iwase, Private communication.

[6] H. Yama-zoye, E. Ichise, H. Fujiwara and M. Iwase, Iron Steelmaker, 18 (5), 75-80 (1991).

[7] M. Iwase, H. Fujiwara, E. Ichise, H. Kitaguchi and K. Ashida, Iron Steelmaker, 16 (4), 45-52 (1989).

[8] E. T. Turkdogan and J. Pearson, J. Iron Steel Inst., 175, 393-401 (1953).

[9] H. Takeshita, M. Hasegawa, Y. Kashiwaya and M. Iwase, Steel Res. Int., 81 (2), 100-104 (2010).

[10] E. T. Turkdogan and J. Pearson, Journal of the Iron and Steel Institute, 175, 393-401 (1953).

[11] M. Matsu-suye, K. Fushi-tani, M. Hasegawa and M. Iwase, Steel Res. Int., 79 (9), 678-684 (2008).

[12] M. Iwase, N. Yamada, H. Akizuki and E. Ichise, Arch. Eisenhüttenwes., 55, 471-476 (1984). 